J. Perinat. Med. 17 (1989) 313

\title{
Ultrasonic evaluation of the normal uterus in the neonate
}

\author{
Kohkichi Hata, Arata Nishigaki, Ken Makihara, Osamu Takamiya, Toshiyuki \\ Hata, and Manabu Kitao
}

Department of Obstetrics and Gynecology, Shimane Medical University, Izumo, Japan

\section{Introduction}

With improvement in real-time ultrasonic equipment with accurate focussing and resolution, normal values of uterine size have been obtained for prepuberal and postpuberal children $[5,7]$. However, little such information on the uterus of the neonate has been obtained $[4,9]$. We report here our assessments of size of the normal uterus at birth, determined using ultrasound. A discussion of its usefulness is made.

\section{Subjects and methods}

Forty-six full-term girls born of Japanese parents aged $0-7$ days (mean age, 2.73 days) were the subjects studied. The birth weights ranged from $2554 \mathrm{~g}$ to $3762 \mathrm{~g}$ (mean, $3198 \mathrm{~g}$ ) and were within the normal range (between the 10th and 90th percentile) of the standard intrauterine growth curve for the Japanese [8]. Permission was obtained from each mother for the examinations.

All the ultrasound examinations were made following evening breast feeding. At this time the bladder as a sonic window is full and the babies are in a concented state. Serial scans were taken to identify the largest uterine section in the longitudinal view (figure 1). The uterine length (U$\mathrm{L}$ ), cervical length (CE-L), corporeal length (CO$\mathrm{L})$, cervical anteroposterior diameter (CE-APD) and corporeal anteroposterior diameter (COAPD) were measured, using electronic calipers. The widest transverse diameter of the cervix (CETD) and widest diameter of the corporeal body (CO-TD) were also measured, using electronic calipers in the plane orthogonal to the uterine longitudinal axis. The cervical volume (CE-V)

\section{Curriculum vitae}

KoHKICHI HATA, M.D., was born in 1956. He graduated from Shimane Medical University in 1983. Since October 1985 he has been an clinical assistant in the Department of Obstetrics and Gynecology, Shimane Medical University. His main fields of interest include fetal biometry and Doppler ultrasound in Obstetrics and Gynecology.

was calculated from the formula: $4 / 3 \times \pi \times \mathrm{CE}$ $\mathrm{L} / 2 \times \mathrm{CE}-\mathrm{APD} / 2 \times \mathrm{CE}-\mathrm{TD} / 2$ and the corporeal volume $(\mathrm{CO}-\mathrm{V})$ by means of the formula: $4 / 3 \times \pi \times \mathrm{CO}-\mathrm{L} / 2 \times \mathrm{CO}-\mathrm{APD} / 2 \times \mathrm{CO}-\mathrm{TD} / 2$, respectively. The uterine volume (U-V) was obtained as the sum of the CE-V and CO-V. The data were computer stored and subsequently analyzed by paired t-test.

The apparatus used in this study was Aloka SSD$650(3.5 \mathrm{MHz})$.

\section{Results}

The neonatal uterus could be imaged in 41 $(89.1 \%)$ out of 46 infants. In five, the uterus could not be visualized because of an empty bladder or overlying bowel. Thirty-nine $(95.1 \%)$ had an anteverted uterus, $2(5.1 \%)$ retroverted ones and the degree of anteversion or retrover- 


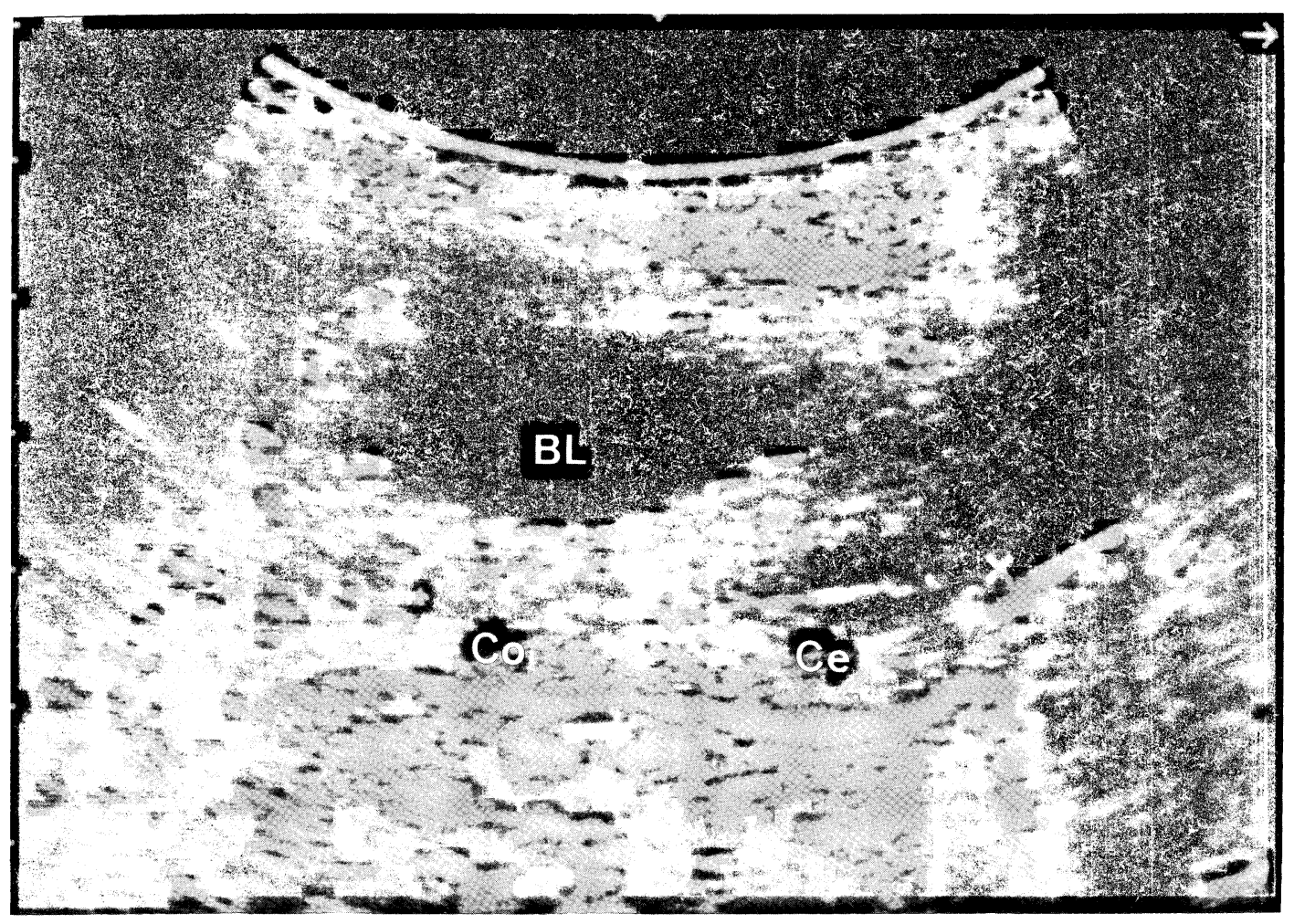

Figure 1. Ultrasonogram of the neonatal uterus, in the longitudinal view. The endometrial echo is clearly visualized as a mixed echo of a highly echogenic line and a myometrial halo.

(BL: bladder, Ce: cervix, Co: Corpus)

sion varied. The values are shown in table I. The length, anteroposterior diameter and transverse diameter of the cervix were significantly longer than those of the corpus, respectively $(\mathrm{p}<0.01$ and $\mathrm{p}<0.001)$. The CE-V was $3.65 \pm 1.36 \mathrm{~cm}^{3}$, the CO-V $1.18 \pm 0.42 \mathrm{~cm}^{3}$ and the CE-V was significantly larger than $\mathrm{CO}-\mathrm{V}(\mathrm{p}<0.001)$. The $\mathrm{U}-\mathrm{V}$ was $4.83 \pm 1.57 \mathrm{~cm}^{3}$, and a good correlation was noted between $U-V$ and birth weight $(\mathrm{r}=0.42, \mathrm{p}<0.01)$. The U-L did not significantly correlate with the birth weight. The endometrial echo could be constantly detected, both within the cervix and corpus, as a mixed echo of a highly echogenic line (figure $2 a$ ) and/ or a myometrial halo (figure $2 b$ ).
Table I. Uterine diameter and volume of the uterus in neonates (mean $\pm \mathrm{SD})$

\begin{tabular}{|c|c|c|}
\hline & \multicolumn{2}{|l|}{ Uterus } \\
\hline & Cervix & Corpus \\
\hline Length (mm) & $21.5 \pm 3.4^{\mathrm{a}}$ & $18.6 \pm 3.4^{\mathrm{a}}$ \\
\hline $\begin{array}{l}\text { Anteroposterior } \\
\text { diameter }(\mathrm{mm})\end{array}$ & $17.1 \pm 2.7^{\mathrm{b}}$ & $10.6 \pm 2.2^{\mathrm{b}}$ \\
\hline $\begin{array}{l}\text { Transverse } \\
\text { diameter }(\mathrm{mm})\end{array}$ & $18.4 \pm 3.0^{c}$ & $11.4 \pm 1.6^{\mathrm{c}}$ \\
\hline Volume $\left(\mathrm{cm}^{3}\right)$ & $3.65 \pm 1.36^{\mathrm{d}}$ & $1.18 \pm 0.42^{\mathrm{d}}$ \\
\hline
\end{tabular}

a: $p<0.01, b, c$ and d: $p<0.001$

Figure 2a. Ultrasonogram of a highly echogenic line (arrow) in the transverse view of the cervix.

Figure 2b. Ultrasonogram of a myometrial halo (arrow) in the transverse view of the corpus. 

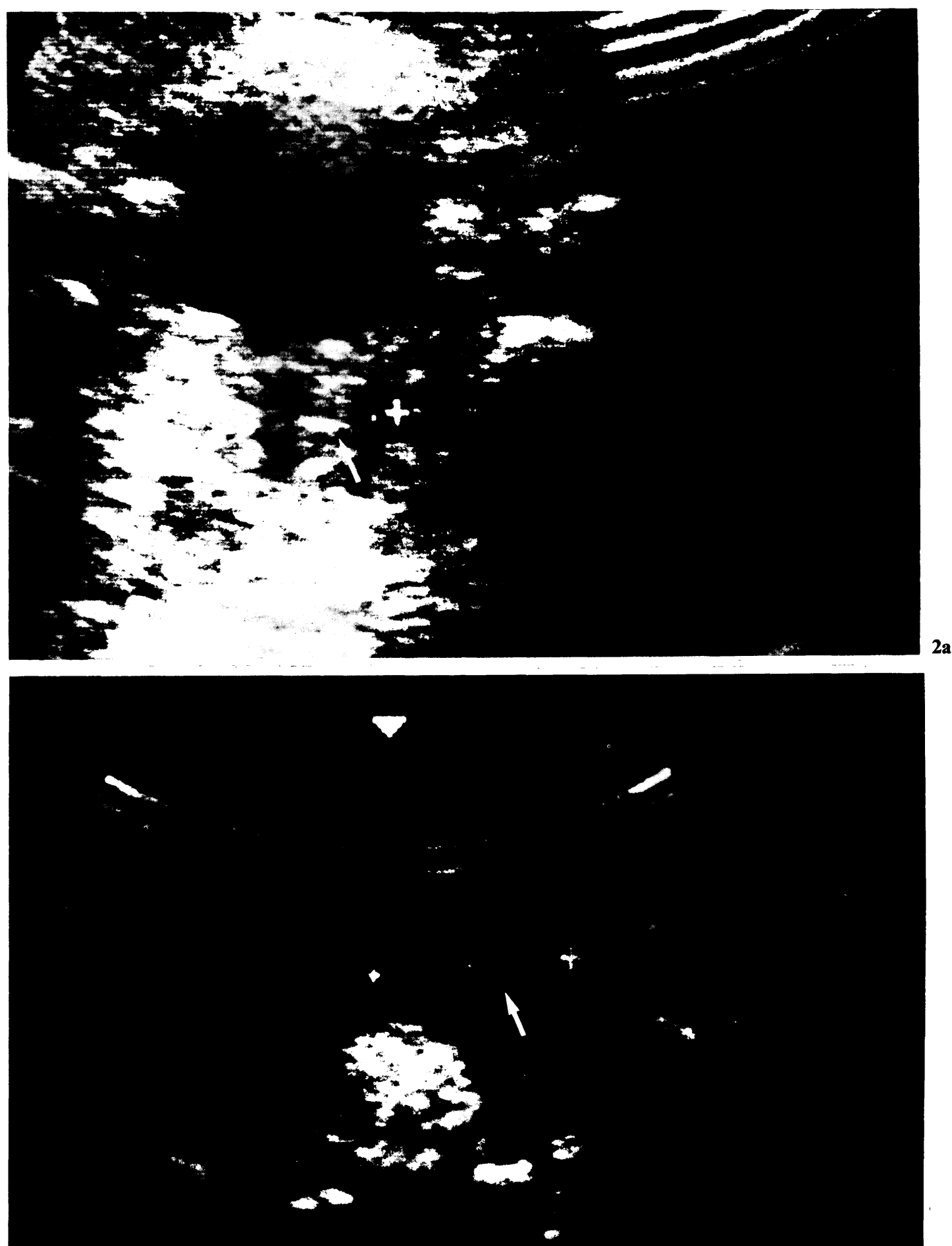


\section{Discussion}

NusSBaUM et al. [4] established the normal values of U-L, $34 \pm 6.5 \mathrm{~mm}$ and mentioned that the U-L showed a significant correlation with birth weight. In the present study, U-L was $38.4 \pm 4.2$ $\mathrm{mm}$ and there was no significant correlation between the U-L and birth weight. The discrepancy in findings in these two studies seems to be due to different techniques used for measuring, race and so on. NusSBAuM et al. [4] also reported the values of CO-APD and CE-APD, but a statistical analysis was not given. In our present study, the length, anteroposterior diameter and transverse diamter of the cervix were significantly longer than those of corpus, respectively. We calculated the CO-V and CE-V by the above formula and noted that the CO-V is larger than the CE-V. Our results obtained using non-invasive ultrasound confirm data from anatomical study that the bulk of the cervix is greater than that of corpus, in the neonate [3]. Consequently, the U-V significantly correlated with birth weight. Although, U-L is a simple parameter for evaluating the uterine size, we think it pertinent to ascertain the uterine volume when making estimation of the uterus in a neonate.

The ultrasonic characteristics seen in the neonatal enodmetrium were a highly echogenic line and/or a myometrial halo. These echos are also recognized by ultrasound during the menstrual

\begin{abstract}
Using real-time ultrasound, a study was undertaken to evaluate the morphology of normal uterus in the neonate delivered at term. The uterus was visualized in $41(89.1 \%)$ of the 46 neonates. The cervical volume (CE-V) was $3.65 \pm 1.36 \mathrm{~cm}^{3}$, the corporeal volume (CO-V) $1.18 \pm 0.42 \mathrm{~cm}^{3}$, and the CE-V was significantly larger than the CO-V $(p<0.001)$. The uterine volume (U-V) was $4.83 \pm 1.57 \mathrm{~cm}^{3}$, and $U-V$ showed
\end{abstract}

Keywords: Evaluation, neonate, uterine morphology.

\section{Zusammenfassung}

Sonographische Untersuchung des normalen Uterus beim Neugeborenen

Mit der Real-time-Sonographie sollte die Morphologie des normalen Uterus von Neugeborenen am Termin untersucht werden. In 41 von 46 Fällen $(\hat{=} 89.1 \%$ ) war der Uterus darstellbar. Das Volumen der Cervix (CE-V) betrug $3.65 \pm 1.36 \mathrm{~cm}^{3}$, das Volumen des Cor- cycle of reproductive women $[1,6]$ and are related to serum estrogen levels [1]. These endometrial echos visualized in the neonatal uterus reflect the production of estrogen by the placenta and also that of maternal origin, in late fetal life [2] and would account for the unique hormonal state in neonate.

Estrogenic stimulation plays an important role in antenatal growth of the uterus [3]. These is a rapid decrease in the serum concentration of estrogen in the neonate [2] and anatomic studies revealed a postnatal regression in size of the uterus, mainly during the first postnatal month [3]. The ultrasonic study by ORSINI et al. [5] showed was no change in uterine size up to age seven years old, after which the uterus grew rapidly and steadily. As the $\mathrm{U}-\mathrm{V}$ value of the neonate obtained in our study corresponded to the U-V at age ten years old, as reported by ORSINI et al. [5], the sonographer should keep in mind that the size of the uterus in the neonate is relatively large.

The ultrasonic feature and value of the normal neonatal uterus are thus known. Care should be taken not to mistake a normal uterus for a pathologic pelvic mass in the neonate. Our data will aid in detecting congenital genital disorders in the female neonate. Prospective investigations to quantify sonographic visualization and measurements of the neonatal uterus are underway.

a good correlation with birth weight $(r=0.42$, $\mathrm{p}<0.01$ ). The endometrial echo was constantly depicted as a mixed echo of a highly echogenic line and/ or a myometrial halo. These normal values and the morphology of the neonatal uterus provide useful information for distinguishing a possible pathologic pelvic mass and screening of congenital genital disorders.

pus (CO-V) $1.18 \pm 0.42 \mathrm{~cm}^{3}$. D.h., das CE-V war signifikant größer als das $\mathrm{CO}-\mathrm{V}(\mathrm{p}<0.001)$. Das Uterusvolumen (U-V) lag bei $4.83 \pm 1.57 \mathrm{~cm}^{3}$. Es korrelierte gut mit dem Geburtsgewicht $(r=0.42, p<0.01)$. Der Endometriumreflex wurde konstant als eine Mischung aus einer sehr echodichten Linie und/oder einem Myometrium-Halo aufgenommen. Die Kenntnis 
der Normalwerte und der Morphologie des neonatalen Uterus ist zum einen bei der Suche nach angeborenen genitalen Mißbildungen notwendig, zum anderen hilft sie, möglicherweise pathologische Prozesse im Becken davon abzugrenzen.

Schlüsselwörter: Evaluierung, Morphologie des Uterus, Neugeborenes.

\section{Résumé}

Evaluation échographique de l'uterus normal chez le nouveau-né

Nous avons realisé à l'aide d'échographies en temps réel une étude pour évaluer la morphologie de l'utérus normal chez le nouveau-né à terme. L'utérus a été visualisé chez $41(89,1 \%)$ des 46 nouveaux-nés. Le volume cervical (Ce.V.) est de 3,65 $\pm 1,36 \mathrm{Cm} \mathrm{3,} \mathrm{le}$ volume corporéal (CO.V) de $1,18 \pm 0,42 \mathrm{~cm} \mathrm{3,} \mathrm{et} \mathrm{le}$ CE V est significativement plus important que le CO.V $(\mathrm{P}<0,001)$. Le volume utérin (U.V) est de 4,83 \pm
$1,57 \mathrm{~cm} \mathrm{3}$, et il est bien corrélé avec le poids de naussance $(r=0,42, P<0,01)$. L'écho Endométrial est constemment représenté sous la forme d'un écho mixte d'une ligne hautement échogénique et/ou d'un halo myométrial. Ces valeurs normales et la morphologie de l'utérus néonatal fournissent des informations utiles permettant de distinguer une possible masse pelvienne pathologique et de faire le dépistage de troubles génitaux congénitaux.

Mots-clés: Evaluation, morphologie utérine, nouveau-né.

Acknowledgements: We thank M. OHARA for comments.

\section{References}

[1] Fleischer AC, DE Pittaway, RT Beard, Ga THIEME, AL BUNDY: Sonographic depiction of endometrial changes occurring with ovulation induction. J Ultrasound Med 3 (1984) 341

[2] FOREST MG: Function of the ovary in the neonatal and infant. Eur J Obstet Gynecol Reprod Biol 9 (1979) 145

[3] Krantz KE, JP AtKInson: Gross anatomy. Ann NY Acad Sci 142 (1967) 551

[4] Nussbaum AR, RC SANDERS, MD JoNEs: Neonatal uterine morphology as seen on real-time $\mathrm{US}^{1}$. Radiology 160 (1986) 641

[5] Orsini LF, S Salardi, G Pilu, L Bovicelli, E CACCIARI: Pelvic organs in premenarcheal girls: Realtime ultrasonography ${ }^{1}$. Radiology 153 (1984) 113

[6] Sakamoto C: Sonographic criteria of phasic changes in human endometrial tissue. Int J Gynaecol Obstet 23 (1985) 7
[7] SAMPLE WF, BM LiPPE, MT GyePES: Gray-scale ultrasonography of the normal female pelvis. Radiology 125 (1977) 477

[8] Sato A, M Akama, H Yamanobe, K Hoshi, M SuzUKI: Intrauterine growth of live-born Japanese infants between 28 and 42 weeks of gestation. Acta Obstet Gynecol Jpn 34 (1982) 1535

[9] STEWART S, T ClARKE: Ultrasound examination of the lower genital tract in female neonates. Pediatr Adoles Gynocol 2 (1984) 185

Received April 24, 1989. Accepted May 9, 1989.

Kohkichi Hata, MD

Department of Obstetrics and Gynecology

Shimane Medical University

Izumo 693, Japan 
